\title{
Application of GIS Analyses to Identify the Problematic Agricultural Areas in the Course of Land Consolidation
}

\section{Introduction}

One of the main priorities of the European Union's common agricultural policy (UE) and the Rural Development Programme (PROW) is to provide sustainable development of rural areas. An important objective is also to equalize development opportunities, and to maintain a rural agricultural fabric in less favourable areas (ONW), having regard to agricultural and environmental commitments, based on the valorisation index of agricultural production area (WWRPP) in agricultural problem areas (OPR) [1].

The presence of defects in the production space in agriculture can be eliminated by the implementation of coherent and comprehensive strategies of land exchange and consolidation [2].

Land consolidation process plays an important role in the management of rural areas, as it stimulates functions undertaken by the areas: in the economic, social and environmental spheres. Changes in ownership and land use structure offer major opportunities in defining functional and spatial solutions, managing the potential, spatial, social and environmental conflicts [3].

Land consolidation was the first instrument to ensure the development of rural and agricultural areas, according to the Act of 26 March 1982 on land consolidation and land exchange primarily by improving the spatial structures of farms [4]. Currently, the main consolidation objective is to create more favourable conditions in agriculture and forestry [4] and to undertake design and project activities that may lead to improved living conditions in rural areas.

Highly important processes, which contributed to such a significant change, are: the renovation of villages, the implementation of social and technical facilities,

* Kielce University of Technology, Department of Geotechnics, Geomatics and Waste Management, Kielce, Poland

** Rzeszow School of Engineering and Economics, Department of Surveying and Geoinformatics, Rzeszów, Poland 
as well as environmental and natural basis for life protection tasks. Of great importance is land consolidation linked to the construction and modernization of access ways on farms [5].

Another important aspect is lowering of the production costs in agriculture and forestry, the reduction of labour input, and the elimination of structural barriers. It is important to note how indispensable abiotic factors are too: terrain surface, soil type, precipitation, water, air temperature, wind. Rural development also defines demographics, landscapes, economics and public interest aspects.

While carrying out consolidation works, particular attention should be paid to agricultural problem areas and the land use aspect.

There is a substantial body of scholarly literature that suggests many definitions of those problem areas. However, defining them is generally based on single discipline evaluations or on different approaches to the issue. Various scientific studies on the subject use such other terminology as: conflict areas, deficient areas, depression areas, less favourable areas, production reserve areas, disadvantaged areas, danger areas, pathological areas, less developed areas, underdeveloped areas, marginal areas, etc [6].

For the sake of clarity, four definitions of problem areas should be specified, as:

- problem area, related to a general concept of geography, characterised by the presence of negative phenomena ,[...] from the social, economic and technical arena, which causes precise internal anomalies (concerning spatial structure) and also the abnormal area size" [7];

- the major problem areas relate to the parts of the province, where problems deemed to be particularly difficult and troublesome [8];

- areas of low socio-economic and spatial effectiveness, requiring efficiency in planning and implementing regional policy in aiding the problems [9];

- spatial unit, related to more than one abnormal spatial element [6].

Thanks to the consolidation process (OPR) there is a possibility to allocate land to forest management, infrastructure, non-agricultural and non-forestry sectors, development, communication, rural tourism, or leisure activities area, etc. Transformation to ecological feature, hunting plots [10] or to energy crops [11] is also highly beneficial.

When land use planning, however, several aspects should be considered about nature, the landscape, the economy and social origin.

A GIS analyses provide excellent tools, which enable the examination and monitoring of the environment [12], and the spatial relationships between objects [13], as well as to forecast nature phenomena and their consequences [14, 15]. This paper presents possibilities of performing land analysis paying special attention to identifying agricultural problem areas with the use of GIS instruments. The main emphasis has been put on the analysis of the lay of the land and the related parameters, i.e. slopes, aspects, susceptibility to erosion. 


\section{Area of Interest}

The object of the presented analysis is Hłudno village. It is located in the Podkarpackie province, in the district of Brzozów, in the commune of Nozdrzec (Fig. 1). In the Podkarpackie province, agriculture is fragmented to a very high degree. It is characterized by a large labour force and low commerciality of production. Broad geographical diversity makes agricultural activity face specific difficulties. Such activity is maintained under extremely unfavourable climate conditions: lowland areas, sub-mountain and mountain areas, where land use is extremely burdensome [16]. The average total surface of the object amounts to 1265 ha, 1224 ha of which has undergone a consolidation process. The number of parcels in the land consolidation area is 5243 .

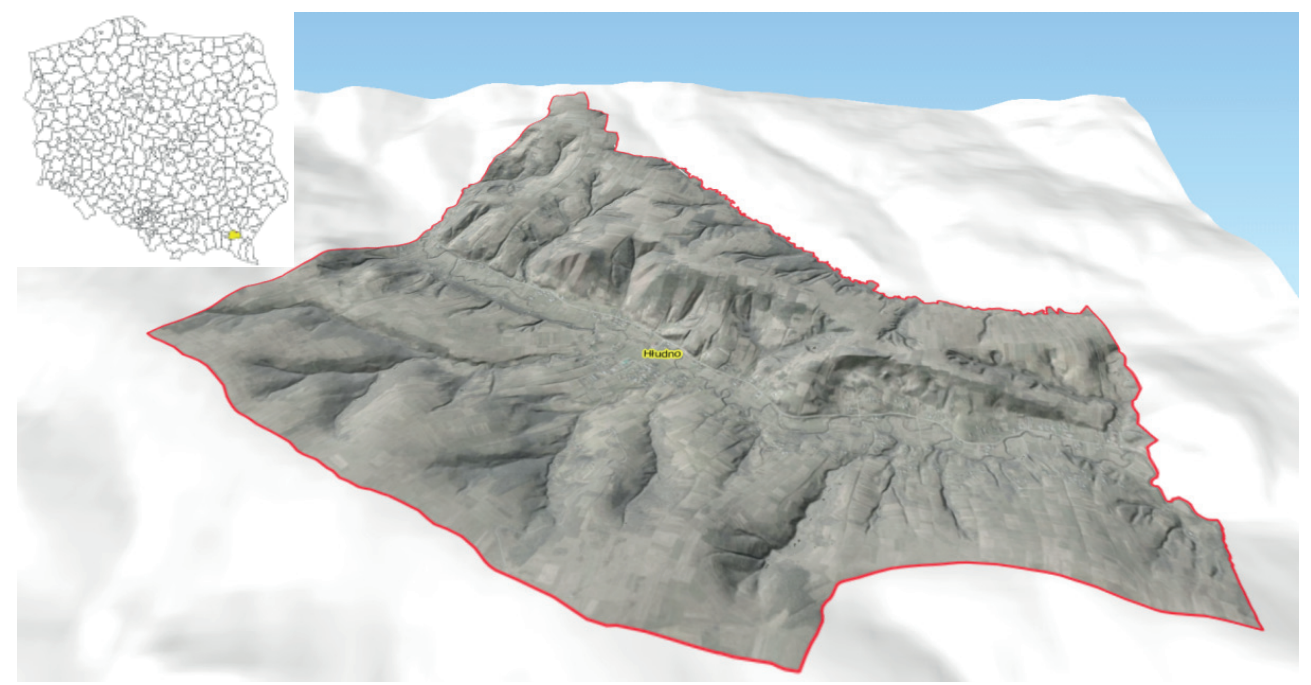

Fig. 1. Localization of Hłudno village (3D view)

\section{Data and Methodology}

The basis for performing the analyses was a SRTM (Shuttle Radar Topography Mission) digital terrain model [17]. According to Guth's research results [18], SRTM data are well suited for spatial analyses (that is e.g. to generate maps of land slopes, average elevations, height differences, etc.) at average land slopes exceeding $5 \%$. In the case of the area of the village of Hłudno under consideration, land slopes range from $0 \%$ to $30 \%$ (Tab. 1 - see p. 51), whereas the difference between the highest point and the lowest point is ca. $170 \mathrm{~m}$ (Fig. 2). Data for the examined area were acquired, free of charge, from the USGS server, in the form of an.hgt file. The raster 
digital terrain model that was utilized had a ground resolution of 3" [17]. SRTM elevation data were read and processed using QGIS/GRASS software. Analyses were performed only for the area confined within the boundaries of the village selected for testing (Figs 1, 2). All 3D map derivatives obtained as a result of the application of procedures, which calculate parameters such as slopes and aspects, were recorded in the PUWG 1992 system.

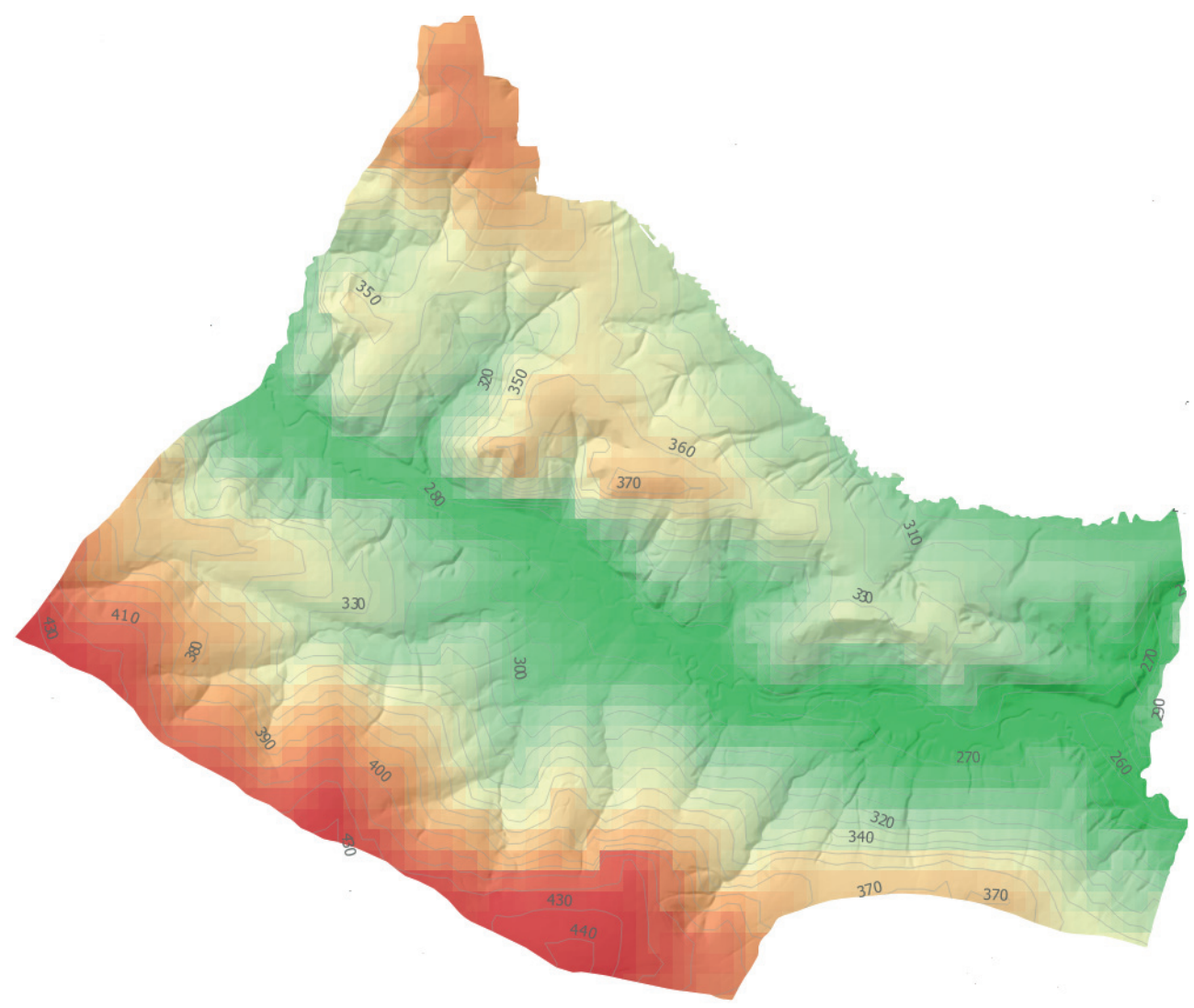

Fig. 2. Visualization of SRTM data for the area of interest (Hłudno village)

The map of the slopes was generated taking into account the parameters determined by [19] (Tab. 1), according to which five ranges of sloping values were prepared (Fig. 3). In the case of the aspects map, the main and indirect geographical directions were calculated and assigned to the azimuth values presented in Figure 4 .

Based on established weight criteria that take into account classification of agricultural problem areas (Tab. 1), the obtained maps of slopes and aspects were subjected to recoding. Eight weights were assigned to the criterion of aspects, and five were assigned to the criterion of land slope. 


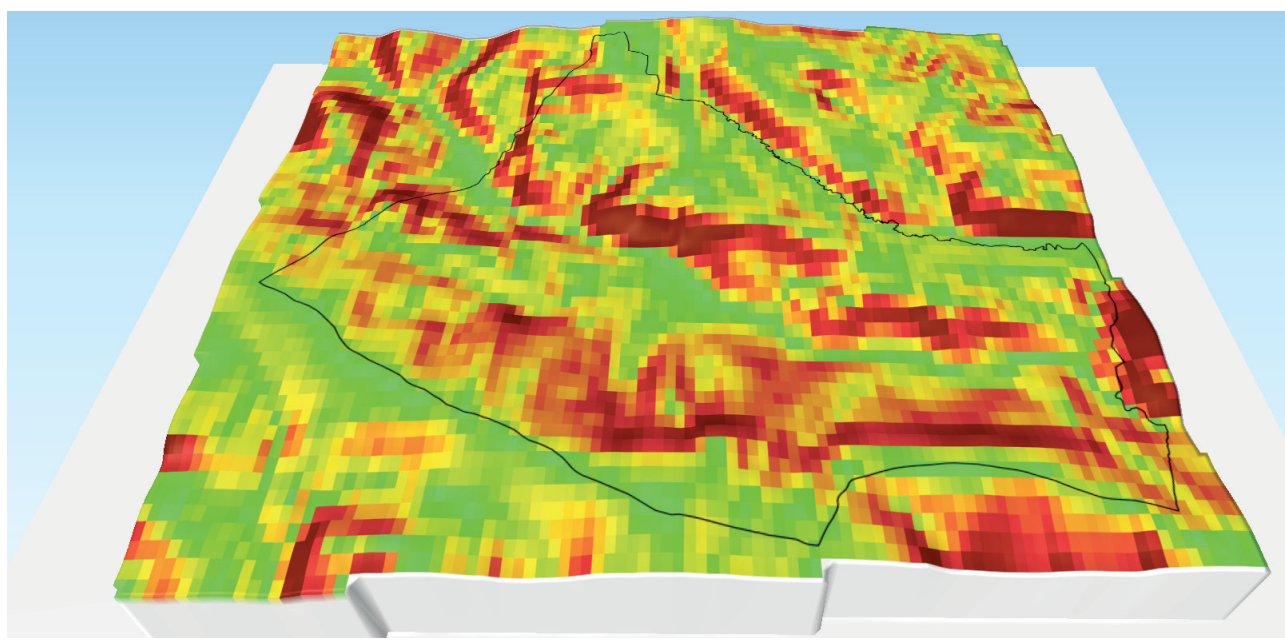

Fig. 3. The 3D map of slopes for Hłudno village

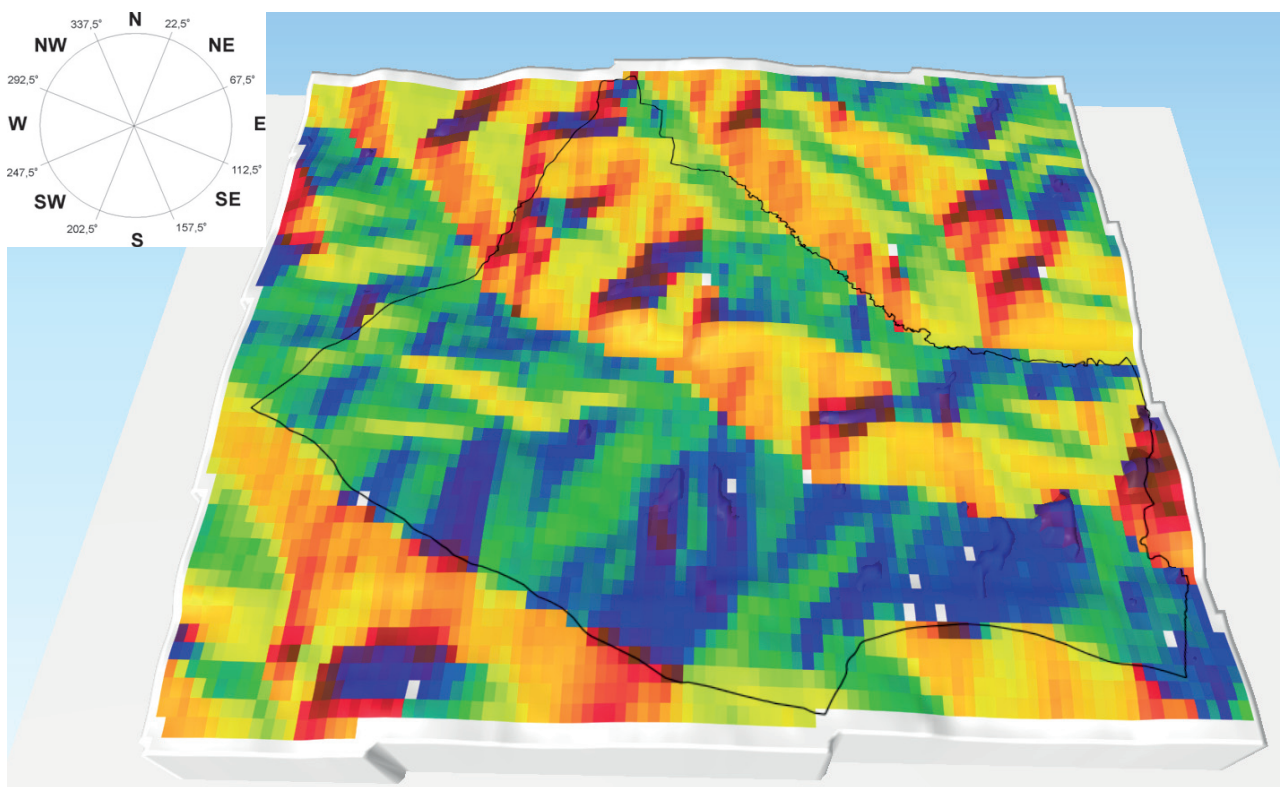

Fig. 4. The 3D map of aspects for Hłudno village

In view of a strong connection between the land slope degree and the land's susceptibility to erosion, based on the obtained land slope map, also a map of land susceptibility to erosion was prepared, assigning five different weights (Fig. 5, Tab. 1). Each weight was selected in accordance with the criteria considered in the course of the agricultural problem areas identification procedures, so the lower the value of a defined weight, the less the problem nature of the given area. 


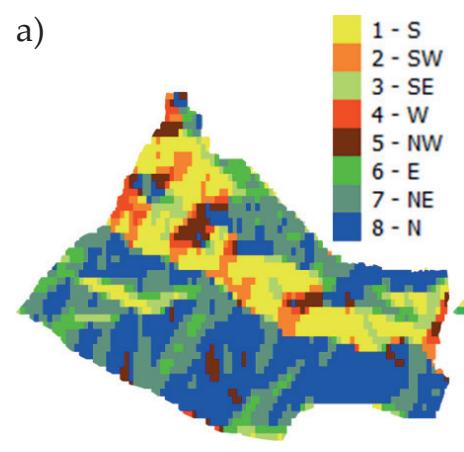

b)

c)

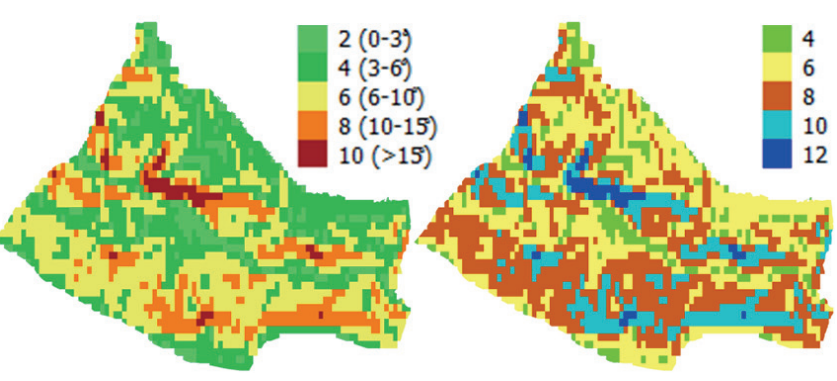

Fig. 5. The maps of weights for each criterion: a) slope; b) aspects; c) erosion

\section{Results of the GIS Analysis}

Based on the prepared, weighted maps of slopes, aspects and erosion, surface areas were obtained for places that were classified according to a relevant criterion (weight) of the lay of the land (Tab. 1). This enabled a detailed analysis of particular areas that belonged to the examined village. Areas of southern and western exposures constituted 30\% (391 ha) of the overall surface area of the village, whereas poorly sun-exposed areas constituted ca. 70\% (874 ha), respectively (Tab. 1, Fig. 5). The analysis of the map of the slopes proved that 573 ha out of the overall village surface area are lands sloped below $10 \%$, which is favourable to agriculture, located in the north and central parts of the village. A large share of the overall surface area of Hłudno (226 ha) is that of land of a very high sloping (sloping exceeds 18\%) (Tab. 1, Fig. 5). High susceptibility to erosion is closely connected just with those areas. Such areas occupy 32 ha of land (Tab. 1, Fig. 5).

Following the completed procedures of the map algebra and reclassification, a final map was obtained, depicting six types of agricultural areas, distinguished in terms of landform conditions (Fig. 6). Values of particular pixels of the map (7-30) constituted the aggregate of the weights of all criteria that had been considered (Fig. 6, Tab. 2). The land types obtained relate to the degree of usability/defectiveness of the agricultural space. The determined land types concern directly specific possibilities of land development or the level of difficulty of the performing land consolidation procedures (type 1 - no limitations, type 6 - very big limitations).

On the basis of results that were obtained in the form of DTM derivative maps (slopes, aspects, susceptibility to erosion), as well as a map of usability/defectiveness of agricultural space, one can state that the village of Hłudno has about 12\% (159 ha) of areas that are agricultural problem areas. The identified land is located mainly in the southern part of the village, where unfavourable land lie conditions related to a very high sloping (in excess of $18 \%$ ) are combined with northern or north-eastern exposures. 
Table 1. Surface areas obtained for particular weights (criteria) determined for maps of aspects, slopes, and erosion

\begin{tabular}{|c|c|c|c|c|c|c|c|c|}
\hline $\begin{array}{l}\frac{n}{0} \\
\tilde{D} \\
\frac{0}{2} \\
\frac{0}{4}\end{array}$ & $\begin{array}{l}\frac{\vec{c}}{b 0} \\
.00 \\
3 \\
3\end{array}$ & 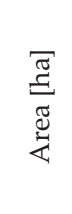 & 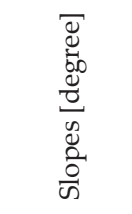 & $\begin{array}{l}\vec{c} \\
\frac{\vec{c}}{60} \\
\overrightarrow{3} \\
3\end{array}$ & $\frac{\widetilde{J}}{\underset{\widetilde{J}}{\tilde{J}}}$ & $\begin{array}{l}\text {.0 } \\
\text {.0 } \\
0 \\
0 \\
\text { D }\end{array}$ & $\begin{array}{l}\overrightarrow{7} \\
\frac{0}{60} \\
\frac{0}{3} \\
3\end{array}$ & 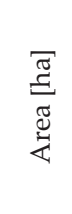 \\
\hline$S$ & 1 & 213 & $\begin{array}{c}<3 \\
(<5 \%)\end{array}$ & 2 & 120 & $\begin{array}{c}1 \text { (very poorly } \\
\text { susceptible to erosion) }\end{array}$ & 4 & 120 \\
\hline SW & 2 & 68 & $\begin{array}{c}3-6 \\
(6-10 \%)\end{array}$ & 4 & 453 & $\begin{array}{c}2 \text { (poorly susceptible to } \\
\text { erosion) }\end{array}$ & 6 & 453 \\
\hline SE & 3 & 78 & $\begin{array}{c}6-10 \\
(10-18 \%)\end{array}$ & 6 & 466 & $\begin{array}{c}3 \text { (moderately } \\
\text { susceptible to erosion) }\end{array}$ & 8 & 466 \\
\hline W & 4 & 32 & $\begin{array}{c}10-15 \\
(18-27 \%)\end{array}$ & 8 & 194 & $\begin{array}{c}4 \text { (strongly susceptible to } \\
\text { erosion) }\end{array}$ & 10 & 194 \\
\hline NW & 5 & 60 & $\begin{array}{l}>15 \\
(>27 \%)\end{array}$ & 10 & 32 & $\begin{array}{l}5 \text { (very strongly } \\
\text { susceptible to erosion) }\end{array}$ & 12 & 32 \\
\hline E & 6 & 97 & - & - & - & - & - & - \\
\hline NE & 7 & 296 & - & - & - & - & - & - \\
\hline $\mathrm{N}$ & 8 & 421 & - & - & - & - & - & - \\
\hline \multicolumn{2}{|c|}{ Sum of area [ha] } & 1265 & - & - & 1265 & - & - & 1265 \\
\hline
\end{tabular}

On the other hand, the area of the most favourable land lie conditions (types 1 and 2) occupies 142 ha and constitutes ca. 11\% of the overall surface area of the cadastral section (Fig. 6, Tab. 2). These are the areas of the Baryczka river valley, and areas in the north-western part of the locality. It should be noted, however, that in addition to the arable land in the area under consideration there are also developed areas (Figs 1, 6). Areas of moderate agricultural conditions (type 3) occupy 32\% (409 ha) of the surface area of the object under examination, and are located in its north part. Those areas, which were identified to be type 4 areas, occupy the biggest (in terms of surface area) part of the village (555 ha), which is ca. $44 \%$ of the overall surface area of the village of Hłudno (Fig. 6, Tab. 2). 
a)

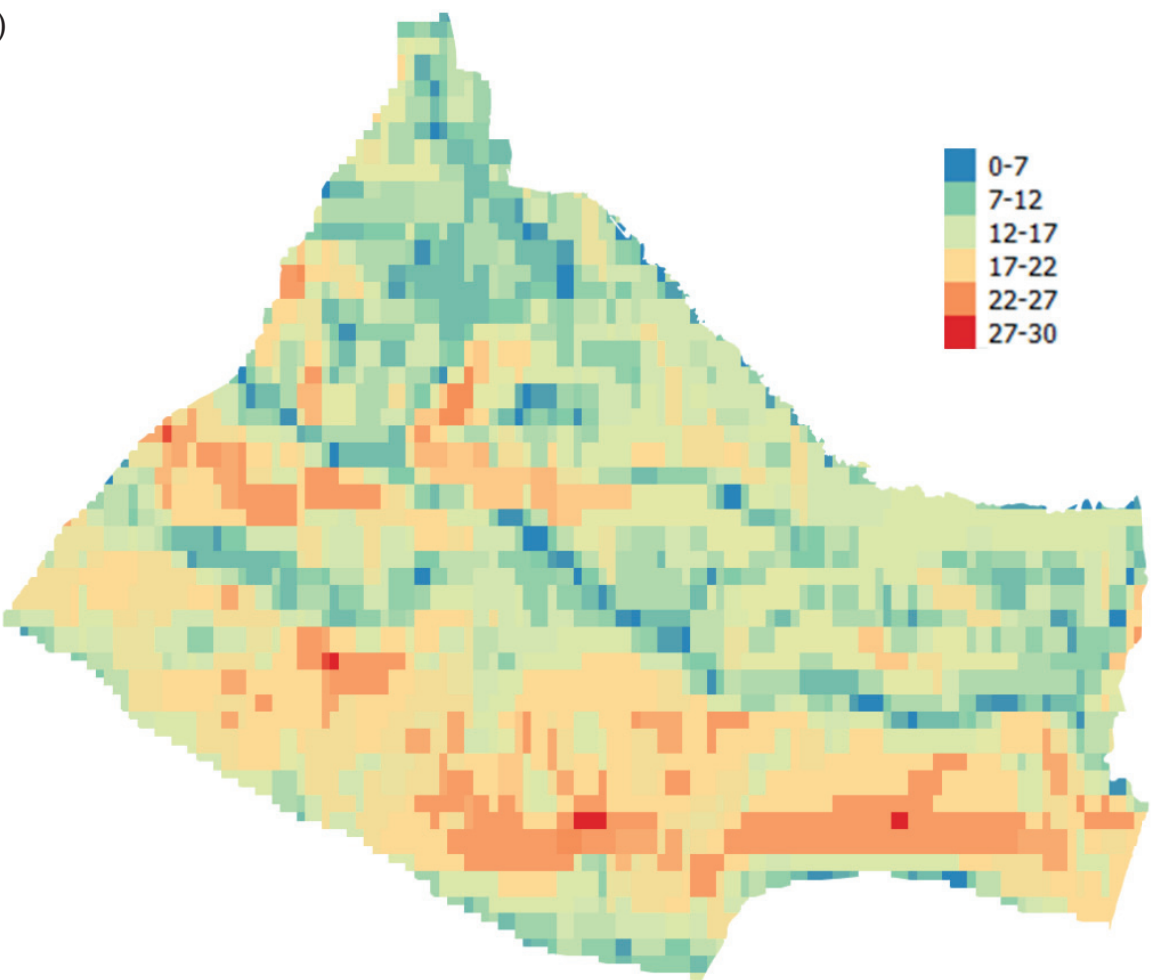

b)

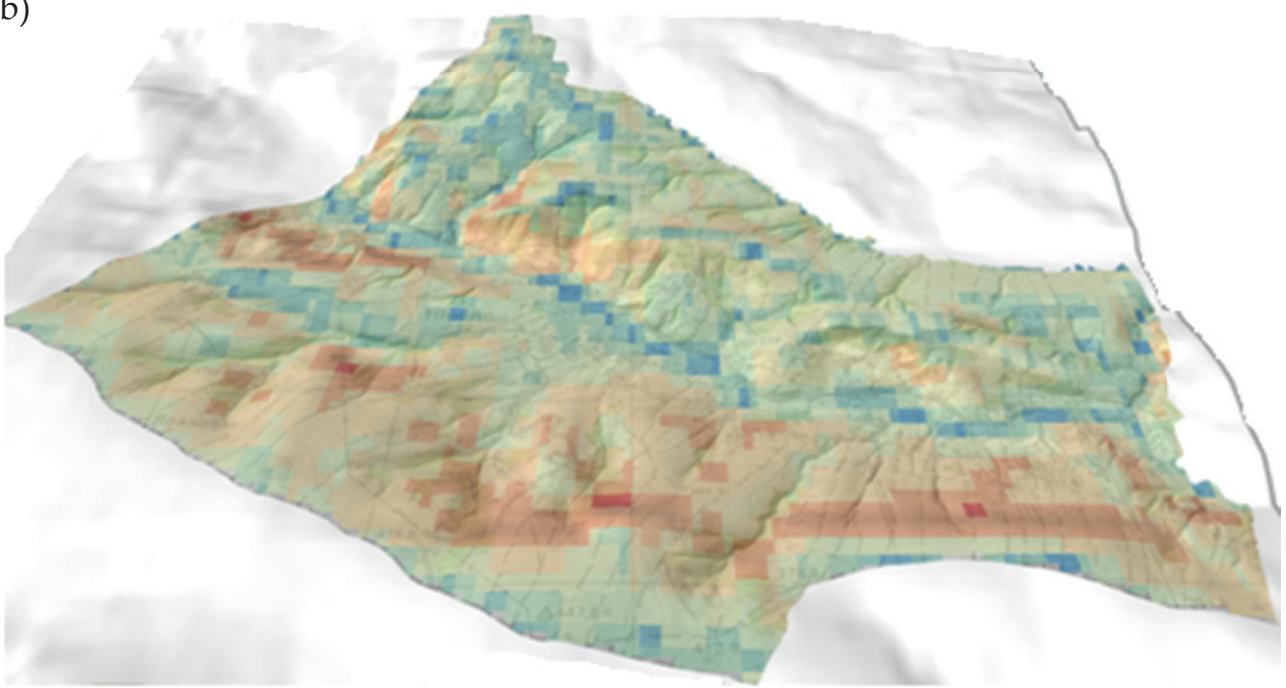

Fig. 6. Map of usability/defectiveness of agricultural space: a) $2 \mathrm{D}$ view; b) 3D view with a topographic map as a background 
Table 2. Results of the identification of agricultural problem areas

\begin{tabular}{|c|c|c||}
\hline $\begin{array}{c}\text { Type of } \\
\text { agricultural areas }\end{array}$ & $\begin{array}{c}\text { Sum of } \\
\text { weights }\end{array}$ & Area [ha] \\
\hline \hline 1 & $0-7$ & 13 \\
\hline 2 & $7-12$ & 129 \\
\hline 3 & $12-17$ & 409 \\
\hline 4 & $17-22$ & 555 \\
\hline 5 & $22-27$ & 157 \\
\hline 6 & $27-30$ & 2 \\
\hline
\end{tabular}

\section{Summary}

The GIS instruments that were applied, together with a set of properly selected spatial data make it possible to precisely outline areas of a specific level of suitability for agricultural purposes. On the basis of research conducted in the village of Hłudno as described herein, there were six types of areas identified, with two of them constituting agricultural problem areas of the total surface area of 159 ha $(12 \%$ of the surface area of the village). That identification was made possible thanks to the properly processed SRTM elevation data, and the use of GIS software-based procedures. The results that have been obtained confirm the justifiability of using spatial analyses in the initial stage of preparing cadastral sections to land integration procedures. As part of the research continuation, the authors propose to utilize DTM data of a higher accuracy (e.g. from lidar data), and to extend the set of criteria by, e.g., soil conditions or demographic and economic determinants, which will surely contribute to obtaining a higher accuracy of agricultural problem areas identification as made with the use of GIS methods.

\section{References}

[1] Dudzińska M., Jasińska E., Kocur-Bera K., Leń P., Preweda E., Sajnóg N., Sobolewska-Mikulska K. (ed.), Steinsholt H., Walacik M., Wójcik J.: Directions for land management in rural areas. Croatian Information Technology Society - GIS Forum, Zagreb, Croatia 2014.

[2] Bajawejder M., Leń P., Wójcik J.: Grunty marginalne, propozycje sposobów ich zagospodarowania w pracach scaleniowych w powiecie brzozowskim. Infrastruktura i Ekologia Terenów Wiejskich, nr 2/II, 2014, pp. 399-410. 
[3] Bielska A., Leń P. (red.), Balawejder M., Bielska A., Gniadek J., Król Ż., Kupidura A., Leń P., Oleniacz G., Sobolewska-Mikulska K., Turek A.: Scalenia gruntów determinantem wielofunkcyjnego rozwoju obszarów wiejskich. WSIE, Rzeszów 2015.

[4] Ustawa z dnia 26 marca 1982 r. o scalaniu i wymianie gruntów. Dz.U. 1982, nr 11, poz. 80 z późn. zm. Tekst jednolity: Dz. U. 2003 nr 178, poz. 1749 [Journal of Laws 1982, no. 11, item 80 with amendments, consolidated text: Journal of Laws 2003, no. 178, item 1749].

[5] Głowienka E., Len P.: Spatial analysis of areas without access to a public road in the villages of the commune Stawno using GIS tools. 20th International Scientific Conference ENVIRO NITRA, November 2015.

[6] Bański J.: Obszary problemowe w rolnictwie Polskim. Prace Geograficzne nr 172, Wydawnictwo Conlinuo PAN, Wrocław 1999.

[7] Zagożdżon A.: Kilka uwag o obszarach problemowych. [in:] Jałowiecki B., Kukliński A., Gospodarka przestrzenna, region, lokalność, Biuletyn - Polska Akademia Nauk, Komitet Przestrzennego Zagospodarowania Kraju 138, PWN, Warszawa 1988, pp. 137-147.

[8] Domański R.: Przestrzenna organizacja rozwoju regionalnego. Studia - Polska Akademia Nauk, Komitet Przestrzennego Zagospodarowania Kraju 93, PWE, Warszawa 1987.

[9] Ciok S.: Sudety obszar problemowy. Acta Universitatis Wratislaviensis 1236, Studia Geograficzne 51, Wyd. Uniwersytetu Wrocławskiego, Wrocław 1991.

[10] Wójcik J.: Proposals concerning management of marginal lands in the land consolidation process in Poland. [in:] Źróbek R., Kereković D. (eds), Management of real estate resources, Croatian Information Technology Society - GIS Forum, Zagreb, Croatia 2013, pp. 51-60.

[11] Sajnóg N., Wójcik J.: Możliwości zagospodarowania gruntów marginalnych i nieużytków gruntowych w scalania gruntów. Infrastruktura i Ekologia Terenów Wiejskich, nr 2/II, 2013, pp. 155-166.

[12] Głowienka E. (red.), Borkowski A., Głowienka E., Hejmanowska B., Kwiatkowska-Malina J., Kwolek M., Michałowska K., Mikrut S., Pękala A., Pirowski T., Zabrzeska-Gasiorek B.: GIS i teledetekcja w monitoringu środowiska. WSIE, Rzeszów 2015.

[13] Michałowska K.: Analizy przestrzenno-czasowe zmian morfologicznych na terenie Stowińskiego Parku Narodowego w latach 1964-2004. Archiwum Fotogrametrii, Kartografii i Teledetekcji, vol. 17, 2007, pp. 473-483.

[14] Hejmanowska B.: Wpływ jakości danych na ryzyko procesów decyzyjnych wspieranych analizami GIS. Uczelniane Wydawnictwa Naukowo-Dydaktyczne AGH, Kraków 2005.

[15] Drzewiecki W.: Analiza krajobrazowo-ekologiczna sposobu użytkowania terenu $z$ wykorzystaniem systemów informacji geograficznej $i$ danych teledetekcyjnych. Akademia Górniczo-Hutnicza, Wydział Geodezji Górniczej i Inżynierii Środowiska 2003 [Ph.D. thesis]. 
[16] Strategia Rozwoju Województwa Podkarpackiego na lata 2007-2020. [on-line:] http://www.podkarpackie.pl/index.php/strategia/2634-sejmik-wojewodztwa-podkarpackiego-przyjal-strategie-rozwoju-wojewodztwa-podkarpackie-2020-wraz-z-prognoza-oddzialywania-na-srodowisko [access: September 2015).

[17] U.S. Releases Enhanced Shuttle Land Elevation Data. [on-line:] http://www2.jpl. nasa.gov/srtm/ [access: September 2015].

[18] Guth P.L.: Geomorphometry from SRTM: Comparison to NED. Photogrammetric Engineering and Remote Sensing, vol. 72 (3), 2006, pp. 269-277.

[19] Józefaciuk C., Józefaciuk A.: Erozja waqwozowa i metody zagospodarowania wawozów. Biblioteka Monitoringu Środowiska, Państwowa Inspekcja Ochrony Środowiska, Warszawa 1996. 